The five speakers will, no doubt, some day be key personnel in food science and nutrition activities in their respective countries where the need for more and better food is often so great.

\title{
REFERENCES
}

Pawley, W. H., Kesteven, K. V. L., Dion, G., Molenaar, A., Silow, R. A., Faunce, A. D., Logothetis, C. \& Ling, L. (1954). World Pop. Conf. Rome, 5, 452.

Platt, B. S. (1956). Int. Congr. Diet. II. Rome, p. 243.

\section{Problems and some solutions: India}

By K. Halder, Human Nutrition Research Unit, National Institute for Medical Research, The Ridgeway, Mill Hill, London, N.W.7

\section{Food production and population growth}

The most pressing problem of India today is that of providing adequate food for the population of 400 million. India had to face this enormous challenge, just after Independence, against the background of the postwar depression and insufficient food production. The Government of India, in the first Five Year Plan, laid maximum emphasis on food production and on improving irrigation systems throughout the country by constructing river-valley projects and setting up fertilizer factories. Food production gradually increased, but the growth of population remained unchecked so that the per caput supply of food is still inadequate. The daily energy value of the food supplies increased from $1700 \mathrm{kcal} /$ head in $1949-50(\mathrm{FAO}, 1953)$ to $1890 \mathrm{kcal}$ in $1955^{-6}$ (FAO, 1958) and the target of $2000 \mathrm{kcal}$ for 1960 (FAO, I953) has already been reached. Even now, however, the energy value of the diets falls below the estimated requirement. In the near future, with further development of agriculture, India will, no doubt, be able to provide adequate calories for the population.

In the early plans, there was little recognition of the nutritional aspects of food policy, and efforts were concentrated almost exclusively on the production of staple foods. In particular, agriculturists were apparently quite unaware of the importance of producing protective foods, or indeed of the need for strenuous efforts to increase the supply of staple foods. Hardly any of them were taught anything about human nutrition. It is, however, beginning to be realized that not only must the production of staple crops be greatly increased but also that the pattern of agriculture will have to be changed in order that in the future the people of India will have enough of the right kind of foods.

\section{Inadequacy of animal products}

India's food balance sheet (FAO, I958) shows a striking deficit of foods of animal origin. The total protein supply is inadequate and, in particular, there is insufficient 
animal protein. Meat production and consumption in India are low because of religious beliefs, traditional and faulty food habits, low economic conditions and unsatisfactory care and feeding of livestock. Egg production is also low because the poultry industry has not been developed. The dairy industry, though more productive, does not yield sufficient cow's milk. The supplies of animal foods and of total and animal protein in India and two technically advanced countries are compared in Table I.

Table I. Total yearly supply of animal food, and mean daily consumption of food of animal origin, total protein and animal protein in India, U.K. and U.S.A., 1954-7 $(F A O$, 1958)

\begin{tabular}{|c|c|c|c|c|c|}
\hline & \multirow[b]{2}{*}{$\underset{\times 10^{-8}}{\text { Population }}$} & \multirow{2}{*}{$\begin{array}{c}\text { Yearly } \\
\text { animal-food } \\
\text { supply } \\
\text { (metric tons } \\
\times 10^{-6} \text { ) }\end{array}$} & \multicolumn{3}{|c|}{ Daily consumption (g/head) } \\
\hline & & & $\begin{array}{l}\text { Animal } \\
\text { food }\end{array}$ & $\begin{array}{l}\text { Total } \\
\text { protein }\end{array}$ & $\begin{array}{l}\text { Animal } \\
\text { protein }\end{array}$ \\
\hline India & 400 & $17 \cdot 42$ & 124.0 & $50 \cdot 4$ & $5 \cdot 3$ \\
\hline U.K. & $5 \mathrm{I}$ & $12 \cdot 47$ & $670 \cdot 1$ & 85.0 & $48 \cdot 9$ \\
\hline U.S.A. & 162 & $43 \cdot 71$ & $827 \cdot 9$ & $94 \cdot I$ & 66.0 \\
\hline
\end{tabular}

The results of dietary surveys carried out in different states of India under the auspices of the Indian Council of Medical Research (Indian Council of Medical Research: Nutrition Advisory Committee, I95 I) are in line with the above information, indicating the low intake of total and animal protein. More recent dietary surveys (Table 2) carried out in Bombay (Radhakrishna Rao, 1956), Delhi (Padmavati, Lakhanpal \& Gupta, I958), the Nilgiri hills of South India (Pasricha, I958) and Calcutta (All India Institute of Hygiene and Public Health: Department of Biochemistry and Nutrition, 1960, unpublished) revealed a similar picture with regard to protein intake.

Table 2. Daily intake/head of calories, total protein and animal protein in four different areas in India

$\begin{array}{lccccc} & \begin{array}{c}\text { I.C.M.R. } \\ \text { recommendations* }\end{array} & \begin{array}{c}\text { Bombay } \\ \text { (W. India) }\end{array} & \begin{array}{c}\text { Delhi } \\ \text { (N. India) }\end{array} & \begin{array}{c}\text { Calcutta } \\ \text { (E. India) }\end{array} & \begin{array}{c}\text { Nilgiris } \\ \text { (S. India) }\end{array} \\ \text { Calories (kcal) } & 2700 & 2588 & 2564 & \mathbf{2 5 8 0} & \mathbf{2 1 5 2} \\ \text { Total protein (g) } & 75 & 70 \cdot 5 & 74 \cdot 2 & 62 \cdot 4 & 49 \cdot 8 \\ \begin{array}{l}\text { Animal protein (g) } \\ \text { Ratio, vegetable protein: }\end{array} & 25 & 7 \cdot 2 & 8 \cdot 2 & 8 \cdot 1 & 6 \cdot 52 \\ \quad & 2: 1 & 8 \cdot 7: 1 & 8: 1 & 6 \cdot 7: 1 & 7 \cdot 2: 1\end{array}$

*Indian Council of Medical Research: Nutrition Advisory Committee (195 I).

Protein malnutrition and the vulnerable groups

Protein malnutrition is most common and serious among certain vulnerable groups in the population, i.e. young children and expectant and nursing mothers. Studies of the diets of pregnant women in a rural area of West Bengal (Bagchi, Halder, Choudhury, Sanyal \& Sen, 1960) revealed that these women do not eat any extra food during pregnancy, but continue to take the ordinary family diet, which has a 
low protein and high carbohydrate content. Similar investigations of the diets of pregnant women in certain regions of South India (Pasricha, I958) showed that they tended to reduce their food consumption in pregnancy to make labour easier.

\section{Lactation and faulty feeding methods}

In the same survey in West Bengal, Bagchi et al. (1960) found that the milk yields of most nursing mothers fell from the 3 rd month of lactation. At this stage, a gruel made of sago boiled in water with a little cow's milk and small quantities of misri (crude cane-sugar) was introduced into the infant's diet. When the infant was 6 months old and secretion of breast milk diminished or even ceased a similar mixed feeding regime was continued because the mother thought that solid food would upset the child's stomach. At this stage the gruel, that was usually given until the age of 18 months, consisted of : 4-6 oz sago, I-2 oz cow's milk, and I oz misri with sufficient water, and was given in six to eight feeds/day. Most of the mothers stated that, though the babies were usually put to the breast up to the age of 2 years, the breast was mainly used as a comforter rather than as a source of food. From is months until they began to receive the usual family diet at about 2 years of age the children were given, in addition to the sago gruel, small quantities of cooked or puffed rice and boiled mashed green plantains.

It is evident that the period 6-r 8 months of age is the most critical. Many children pass through this period without any gross disorder. Others, however, show signs of protein malnutrition. Bagchi et al. ( 1960 ) interrogated mothers of children suffering from protein malnutrition and noted that there was invariably a history of protracted diarrhoea in the child before it developed the condition. It was observed that as soon as the diarrhoea began the mothers stopped giving the small quantity of cow's milk and kept the child on a starchy diet, because they thought that milk aggravated diarrhoea.

The incidence of protein malnutrition in children in various parts of India has been investigated by Gopalan (1956), Srikantia, Sriramachari \& Gopalan (1958) and by Rao, Swaminathan, Swarup \& Patwardhan (1959). The last of these studies was the most comprehensive. It was undertaken in four states of South India and covered 4536 children, a large majority of whom were found to show signs of protein malnutrition. The authors estimated that about 12000 children in a population of 94.8 million in the area surveyed were suffering from this condition.

\section{Solutions}

The permanent solution of the problem of undernutrition and malnutrition in India calls for expensive long-term measures, including the following:

(I) Increasing the output of livestock products by improving the feeding, management and breeding of cattle and reducing losses from disease.

(2) Increasing the output of dairy and poultry products on a large scale.

(3) Increasing fish production by cultivating fish in ponds and rice fields and developing sea fisheries, 
(4) Above all by increasing the purchasing power of the people and reducing illiteracy.

But until such long-term measures yield results, certain short-term, less expensive, measures are being adopted in India to improve the nutritional status of the people. They include:

(I) Encouragement of the cultivation and popularization of the use by rural people of cheap, locally available foods, rich in vegetable protein, e.g. Bengal gram (Cicer arietinum), groundnut (Arachis hypogaea), soya bean (Glycine hispida) and various pulses.

(2) Cookery demonstrations of the preparation of acceptable dishes from such foods by trained dietitians and public health nurses in the rural areas.

(3) Encouragement of mothers to give suitable and nutritionally adequate diets to infants after 6 months of age.

Food scientists and technologists can help by devising mixtures, preferably based on locally available foodstuffs, that will satisfy the following criteria:

(I) contain sufficient good-quality protein after processing as shown by appropriate biological and chemical tests; (2) contain other nutrients in adequate and balanced amounts; (3) contain no toxic principles; (4) meet a specified minimal bacteriological standard; $(5)$ be easily stored in tropical climates without spoilage; (6) be easily packaged for transport and for convenient distribution; (7) be of a price within the means of poorer classes; $(8)$ be generally acceptable; (9) be easily incorporated in the diets of infants and children; (ro) have no adverse effects on the infant's digestion; (I I) be demonstrably conducive to good health, growth and development.

It will obviously be necessary to test such products according to these criteria before they are recommended for general use.

\section{REFERENCES}

Bagchi, K., Halder, K., Choudhury, S. R., Sanyal, B. \& Sen, P. C. (1960). F. Indian med. Ass. 34, 441. FAO. (1953). Second World Food Survey, p. 49. Rome: Food and Agriculture Organization of the United Nations.

FAO. (1958). Food Balance Sheets (1954-56 Average). Rome: Food and Agriculture Organization of the United Nations.

Gopalan, C. (r956). F. trop. Pediat. x, 206.

Indian Council of Medical Research: Nutrition Advisory Committee. (195I). Spec. Rep. Ser. Indian med. Res. Coun. no. 20, p. 21.

Padmavati, S., Lakhanpal, R. K. \& Gupta, S. (1958). Indian f. med. Res. 46, 834.

Pasricha, S. (1958). Indian F. med. Res, 46, 605.

Radhakrishna Rao, M. V. (1956). Diet and Nutrition Studies in the Rural Areas of Bombay State, p. 67. Bombay: Government Printer.

Rao, K. S., Swaminathan, M. C., Swarup, S. \& Patwardhan, V. N. (1959). Bull. World Hlth Org. 20, 603 .

Srikantia, S. G., Sriramachari, S. \& Gopalan, C. (1958). Indian F. med. Res. 46, 121. 